\title{
ARTYKUtY
}

Klio. Czasopismo poświęcone dziejom Polski i powszechnym

PL ISSN 1643-8191, t. 50 (3)/2019, s. 21-42

(c) (1) $\Theta$

http://dx.doi.org/10.12775/KLIO.2019.035

SEBAstian RajeWicz

\section{Społeczne i polityczne aspekty hodowli koni w Sparcie epoki klasycznej ${ }^{* *}$}

\section{Social and political aspects of horse breeding in classical Sparta}

Streszczenie: Celem artykułu jest zbadanie zjawiska spartańskiej hippotrophii ze szczególnym uwzględnieniem trzech zagadnień: uczestnictwa Spartan i Spartanek w konnych zawodach sportowych (hippikoi agones), organizacji hodowli (koszty, rodzaje koni, infrastruktura) i społecznych implikacjach hodowli koni w polis lacedemońskiej epoki klasycznej. Zachowane świadectwa źródłowe wskazują, że cieszyła się ona popularnością wśród elity spartańskiej, pozwalając jej na manifestację statusu i okazję do powiększania kapitału politycznego. Analiza przypadku Kyniski, która jako pierwsza kobieta w dziejach sięgnęła po laur olimpijski, dobrze pokazuje powiązania hodowli z polityką.

* Instytut Historyczny Uniwersytetu Warszawskiego, Krakowskie Przedmieście 26/28, 00-927 Warszawa, s.rajewicz@gmail.com, ORCID: 0000-0001-9802-6441.

** Praca naukowa finansowana ze środków budżetowych na naukę w latach 2015-2019 jako część projektu badawczego pt. „Tethrippon Euagorasa. Schole w Sparcie w V-IV wieku p.n.e.” realizowanego w ramach programu pod nazwą „Diamentowy Grant”. 


\begin{abstract}
The aim of the article is to examine the phenomenon of Spartan hippotrophia, focusing on three issues: participation of Spartan men and women in horse racing (hippikoi agones), organization of breeding (costs, types of horses, infrastructure) and social implications of horse breeding in the Lacedaemonian state of the classical era. Preserved source material indicates that it enjoyed popularity among Spartan elite, allowing them to manifest their status and giving the opportunity to make political capital. Analysis of the case of Cynisca, the first woman who reached for the Olympic laurels, shows well the links between breeding and politics.
\end{abstract}

Słowa kluczowe: hodowla koni, Kyniska, Sparta, tethrippon

Keywords: horse breeding, Cynisca, Sparta, tethrippon

๓工 $\begin{gathered}\text { acedemończycy po najeździe perskim przyłożyli się najgorliwiej ze } \\ \text { wszystkich Hellenów do hodowli koni”. Zdanie to wypowiada Pau- }\end{gathered}$ zaniasz ${ }^{1}$, będąc pod wrażeniem liczby posagów olimpioników spartańskich, które widział w Olimpii podczas swojej słynnej wędrówki. Rzeczywiście od pewnego momentu spartańskie czterokonne zaprzęgi (tethrippa) regularnie odnosily zwycięstwa na igrzyskach olimpijskich. Wiemy, że obywatele Sparty brali udział i zwyciężali również w innych panhelleńskich igrzyskach w Delfach, Nemei i na Istmie oraz w zawodach organizowanych na terytorium polis lacedemońskiej. Materiał źródłowy, nie tylko na tym przykładzie, ale także w innych miejscach, poświadcza wyraźnie, że hodowla koni (hippotrophia) cieszyła się nad Eurotasem dużą popularnością. Tymczasem do schyłku XX wieku hippotrophia w klasycznej Sparcie nie doczekała się szerszego omówienia. W opracowaniach poświęconych samej Sparcie wspomina się o niej zwykle mimochodem przy okazji refleksji nad oliganthropią, nierównościami majątkowymi w obrębie wspólnoty obywatelskiej albo przy opisie udziału Spartan w agonach sportowych ${ }^{2}$. W pracach ogólnych

1 Paus. 6, 2, 1, tłum. J. Niemirska-Pliszczyńska.

2 Np. E. Baltrusch, Sparta: Geschichte, Gesellschaft, Kultur, München 1998, s. 82; P. Cartledge, Agesilaos and the Crisis of Sparta, London 1987, s. 149-150; A. Powell, Athens and Sparta: Constructing Greek Political and Social History from 478 BC, London 2001, s. 231; P. Cartledge, Sparta and Lakonia: A Regional History, 1300-362 BC, London 
dedykowanych hodowli koni i jeździectwu w Grecji kwestie spartańskie nie zajmują wiele miejsca ze względu na szczególną specyfikę tego rodzaju publikacji ${ }^{3}$. Kładą one bowiem zwykle największy nacisk na zagadnienia o charakterze technicznym, a źródła do historii Sparty nie są na ogół w takich wypadkach instruktywne. Brak stosownych informacji źródłowych (a przynajmniej niewielka ich ilość) wpływa także na niemal całkowita nieobecność Sparty i hippotrophii w rozprawach z zakresu animal studies, stawiających sobie za cel zbadanie stosunku człowieka do zwierząt ${ }^{4}$. Hodowla koni w Sparcie znalazła się w centrum rozważań dopiero u Stephena Hodkinsona w 10. rozdziale jego opus magnum ${ }^{5}$. Anton Powell stwierdził, że praca „w sposób definitywny zbadała związki pomiędzy bogatymi Spartanami a końmi"'. Trudno się nie zgodzić. Stephen Hodkinson w imponujący sposób opisał proces wykorzystywania bogactwa przez przedstawicieli elity spartańskiej do zapewnienia sobie zwycięstwa w zawodach hippicznych, a przez to zyskania prestiżu ułatwiającego nawiązywanie kontaktów za granicą i pozyskiwanie wpływów politycznych w ojczyźnie. W wielu wypadkach podążam za jego wywodami. Celem niniejszego artykułu jest ukazanie wpływu, jaki wywierała hippotrophia na życie społeczne i polityczne klasycznej Sparty. Będzie się on składać z trzech części: omówienie udziału Spartan w agonach będzie służyło oszacowaniu popularności zjawiska; refleksja nad wybranymi elementami organizacji hodowli pozwoli uchwycić jego społeczny kontekst; wreszcie analiza przypadku Kyniski umożliwi nie tylko przedstawienie politycznych implikacji hippotrophii, ale także

2002, s. 142, 149-150, 199-200; S. Pomeroy, Spartan Women, London 2002, s. 19-24; R. Kulesza, Sparta $w$ V-IV w. p.n.e., Warszawa 2003, s. 26-27.

3 Np. J.K. Anderson, Ancient Greek Horsemanship, Berkeley \& Los Angeles 1961, s. 136-137; C. Willekes, The Horse in the Ancient World: From Bucephalus to the Hippodrome, London \& New York 2016, s. 128-129.

4 Wnioski na temat stosunku Spartan do koni na podstawie zachowanych imion spartańskich wyciagał N. Richer, Elements of the Spartan Bestiary in the Archaic and Classical Period, [w:] Sparta: The Body Politic, red. A. Powell, S. Hodkinson, Swansea 2010, s. 5-9, 22.

5 Property and Wealth in Classical Sparta, Swansea 2000, s. 303-333.

6 A. Powell, op. cit., s. 262, przyp. 119. 
nakreślenie konsekwencji, które działalność Kyniski przyniosła antycznej refleksji nad rolą kobiet w Sparcie.

Spośród wszystkich konnych zawodów sportowych (hippikoi agones) udział Spartan w igrzyskach olimpijskich jest najlepiej poświadczony źródłowo. Dysponujemy listą spartańskich zwycięzców olimpijskich, która została opracowana przez Luigiego Morettiego ${ }^{7}$ i zrewidowana przez Stephena Hodkinsona $^{8}$. Dokładne daty poszczególnych sukcesów nie są pewne (z wyjątkiem zwycięstwa Lichasa w 420 roku p.n.e. za sprawą Thuk. 5, 50), ale zostały przekonująco uargumentowane. Lista przedstawia się następująco':

\begin{tabular}{|c|c|c|}
\hline \multicolumn{2}{|c|}{ Olimpionicy spartańscy w tethripponie } \\
\hline Data (p.n.e.) & Zwycięzca (Moretti) & Zwycięzca (Hodkinson) \\
\hline 548 & Euagoras & Euagoras \\
544 & Euagoras & Euagoras \\
540 & Euagoras & Euagoras \\
504 & Demaratos & Demaratos \\
484 & Polypeithes & Polypeithes \\
448 & Arkesilaos & Arkesilaos \\
444 & Arkesilaos & Arkesilaos \\
440 & Polykles & Leon \\
432 & Lykinos & Ksenarkes (?) \\
428 & Anaksandros & Anaksandros \\
424 & Leon & Polykles (?) \\
420 & Lichas & Lichas \\
396 & Kyniska & Kyniska \\
392 & Kyniska & Kyniska \\
388 & Ksenarkes (?) & \\
384 & - & Lykinos \\
lub później & & \\
\hline
\end{tabular}

W Olimpii zwyciężyły ponadto dwie inne osoby ze Sparty: Eurybiades w wyścigu kwadryg źrebaków, zwykle dwulatków (tethrippon polikon), w 384 roku p.n.e., kiedy konkurencja ta weszła do programu igrzysk, oraz

7 L. Moretti, Olympionikai, i Vincitori negli Antichi Agoni Olimpici, Rome 1957, s. $53 \mathrm{i} \mathrm{n.}$

8 S. Hodkinson, op. cit., s. 308, przyp. 11.

9 Za: ibidem, s. 308. 
Spartanka Euryleonis, której dwukonny zaprzęg (synoris) okazał się najlepszy w 368 roku p.n.e. Co do zawodów hippicznych o zasięgu ogólnogreckim a rozgrywanych poza Olimpią, materiał źródłowy jest bardzo ubogi. Posiadamy informacje o udziale w dwóch typach zawodów sportowych. Ksenarkses i Polykles (obaj zwyciężali w Olimpii) odnosili zwycięstwa także w Delfach, Nemei i na Istmie ${ }^{10}$. Słyszymy o ich sukcesie ze względu na wyjątkowość osiągnięcia: uzyskanie miana periodoniksa, zwycięzcy na wszystkich igrzyskach panhelleńskich, było powodem do szczególnej chwały, ale z pewnością nie byli to jedyni Spartanie, którzy starali się o laury poza Olimpią. Spartanie wystawiali rydwany również $\mathrm{w}$ agonach organizowanych podczas Wielkich Panatenajów. Świadczą o tym znalezione w świątyni Ateny Chalkioikos oraz Menelaionie datowane na drugą połowę VI wieku p.n.e. fragmenty amfor, które otrzymywali w nagrodę zwycięzcy agonów. Niektóre z nich przedstawiają czterokonne rydwany podczas wyścigu ${ }^{11}$.

W świetle powyższego zestawienia uwaga Pauzaniasza wydaje się nieprecyzyjna, ponieważ przez trzydzieści lat od zakończenia wojen perskich nie słyszymy o spartańskim sukcesie w Olimpii. Wydaje się niedokładna tylko z naszej perspektywy. Dla autora piszącego w II wieku n.e. wojny perskie były naturalnym punktem odniesienia ${ }^{12}$. W istocie spartańskie tethrippony zaczynają regularnie wygrywać od początku drugiej połowy $\mathrm{V}$ wieku p.n.e. $\mathrm{Z}$ wyjątkiem jednych wszystkie igrzyska między 448 a 420 rokiem p.n.e., kiedy to Sparta została wykluczona z udziału w zawodach ${ }^{13}$, kończyły się uwieńczeniem jej obywateli. Zaraz po cofnięciu zakazu w 400 lub 396 roku p.n.e. tendencja ta była kontynuowana: po laur dwukrotnie z rzędu sięgała Kyniska, po niej Ksenarkes (Moretti) lub Lykinos (Hodkinson) oraz Eurybiades, można więc przypuszczać, że gdyby nie zawirowania wojny peloponeskiej, liczba spartańskich zwycięstw w Olimpii byłaby większa (a i tak jest przecież imponująca: od połowy V do lat osiemdziesiątych IV wieku p.n.e. Sparta zdobyła ponad połowę wszystkich wieńców olimpijskich w tej

10 Paus. 6, 1, 7; 6, 2, 2.

11 Zob. G. Dickins, Evocations at Sparta 1907: S 7. The Hieron of Atena Chalkioikos, "The Annual of the British School at Athens" 1907, t. 13, s. 150-152; J.D. Beazley, Attic Black-Figure Vase-Painters, Oxford 1956, s. 369.

12 S. Hodkinson, op. cit., s. 309.

13 Thuk. 5, 50; Xen. Hell. 3, 2, 21; Diod. 14, 17, 4. 
dyscyplinie $)^{14}$. Co prawda już wcześniej zdarzała się seria spartańskich zwycięstw w postaci niezwykłych, trzykrotnych sukcesów zaprzęgu Euagorasa (oprócz niego, jak zaświadcza Hdt. 6, 103, dokonał tego jedynie Kimon z Aten, ojciec sławnego Miltiadesa), ale w przypadku sukcesów z lat 448-420 regularność ta była innego rodzaju: tutaj wieniec zdobywał niemal za każdym razem inny Spartanin. Dowodzi to istnienia grupy hodowców koni w Sparcie, dla których Olimpia oraz inne zawody sportowe stały się polem zaciętej rywalizacji.

Poza agonami panhelleńskimi Spartanie brali udział w zawodach organizowanych na terytorium polis lacedemońskiej. Świadectwem takiego uczestnictwa jest stela niejakiego Damonona z pokaźną inskrypcją ${ }^{15}$ (zachowały się 94 wiersze) uwieńczoną reliefem przedstawiającym tethrippon w trakcie wyścigu. Została ona odnaleziona w sanktuarium Ateny Chalkioikos na spartańskim akropolu i jest datowana na okres bezpośrednio poprzedzający wojnę peloponeską albo okres bezpośrednio po niej następujący ${ }^{16}$. Jest to skrupulatny wykaz sportowych zwycięstw Damonona i jego syna, Enymakratidasa, głównie hippicznych, ale także biegowych, rodzaj sportowego curriculum vitae $^{17}$. I tak inskrypcja wymienia co najmniej (ze względu na ubytki nie znamy dokładnej liczby) 43 zwycięstwa w wyścigach czterokonnych zaprzęgów (tethrippon) i 21 zwycięstw w wyścigach na grzbiecie konia (keleks). Jedynie trzy wiktorie w keleks należały do Enymakratidasa, cała reszta była osiągnięciem Damonona. Zawody odbywały się w trakcie obchodów siedmiu odrębnych świąt (inskrypcja podaje ich łącznie dziewięć $)^{18}$, mających miejsce $\mathrm{w}$ różnych zakątkach państwa spartańskiego:

${ }^{14}$ Ch. Mann, Athlet und Polis im archaischen und frühklassischen Griechenland, Göttingen 2001, s. 140-141.

15 Inscriptiones Graecae V, 1, 213.

16 H.J.W. Tillyard, Laconia: I. Excavations at Sparta, 1907: \& 10. Inscriptions, „The Annual of the British School at Athens" 1907, t. 13, s. 181-182; L.H. Jeffery, The Development of Laconian Lettering: A Reconsideration, „The Annual of the British School at Athens” 1988, t. 83, s. 179-181; J. Ducat, Esclaves au Ténare, „Mélanges Pierre Lévêque” 1990, t. 4, s. 179-180; S. Hodkinson, op. cit., s. 306-307.

17 P. Cartledge, op. cit., s. 199.

18 Szeroko na ten temat: M. Nafissi, La stele di Damonon (IG V 1, $213=$ Moretti, IAG 16), gli Hekatombaia (Strabo 8,4,11) e il sistema festivo della Laconia d'epoca classica, „Aristonothos” 2013, t. 8, s. 126-133; zob. także: H.J.W. Tillyard, op. cit., s. 179-181. 
w samej Sparcie, w Thourii w Messenii, w Helos w południowej Lakonii, w Tyreii. Damonon przedstawia się w inskrypcji jako hodowca z prawdziwego zdarzenia, wielokrotnie podkreślając, że zwycięskie konie pochodzą z prywatnej hodowli jako zrodzone $\mathrm{z}$,jego własnej klaczy i jego własnego

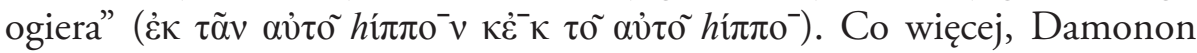
chwali się, że sukcesy odnosił samodzielnie, osobiście powożąc zaprzęgami

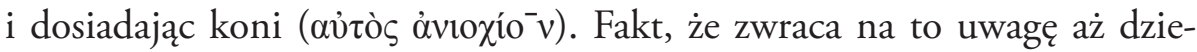
więciokrotnie, świadczy, że poczytywał sobie to za powód do szczególnej chwały. Rzeczywiście regułą w świecie greckim było, że fundator zaprzęgów raczej nimi nie powoził, a zatrudniał do tego wykwalifikowanego woźnicę (zwycięzcą agonu pozostawał zawsze właściciel koni). Być może właśnie ten fakt przyczynił się do tego, że Damonon otrzymał możliwość wystawienia steli. W Sparcie bowiem istniały do pewnego momentu ograniczenia co do publicznego upamiętniania sukcesów sportowych, szczególnie tak „snobistycznych"19, jak hippikoi agones ${ }^{20}$. Damonon miał uzyskać ten przywilej właśnie ze względu na wyjątkowe osobiste zaangażowanie podczas licznych wyścigów, dając w ten sposób dowód swojej cnoty atletycznej, takiej, jaką podziwiano u tryumfatorów w gymnikoi agones. Udowodnił to zresztą i na innych polach, wygrywając wielokrotnie biegi na dystansie jednego i dwóch stadionów, o czym nie omieszkał wspomnieć w inskrypcji. Z tego więc powodu należało mu się prawo postawienia steli, to samo, które jako jedyni posiadali zwycięzcy lokalnych zawodów gymnicznych ${ }^{21}$. W świetle powyższych rozważań nieprzypadkowy wydaje się fakt, że stela Damonona to jedyny tego typu zabytek, który przetrwał do naszych czasów.

Za sukcesami Damonona stały nie tylko zaangażowanie i wyjątkowy talent jeździecki, ale także dobra organizacja hodowli. Efektywna hippotrophia wymagała spełnienia określonych warunków. Przede wszystkim - posiadania dużego zasobu pieniędzy. Koszty były wysokie i różnego rodzaju.

19 S.G. Miller, Starożytni olimpijczycy, tłum. I. Żółtowska, Warszawa 2006, s. 77.

20 S. Hodkinson, An Agonistic Culture? Athletic Competition in Archaic and Classical Spartan Society, [w:] Sparta: New Perspectives, red. S. Hodkinson, A. Powell, Swansea 1999, s. 152-176.

21 S. Hodkinson, Property and Wealth in Classical Sparta, Swansea 2000, s. 305-306; P. Christesen, Sparta and Athletics, [w:] A Companion to Sparta, red. A. Powell, t. 2, Chicester 2018, s. 553. 
Ceny koni zależały od wieku, rodzaju użytkowania i rasy. Jak wynika z Xen. Ages. 9, 6, w Sparcie hodowlę koni bojowych wyraźnie odróżniano od hodowli koni wyścigowych. Podział ten datuje się przynajmniej od roku 424 p.n.e., w którym powstała spartańska kawaleria ${ }^{22}$. Obowiązek dostarczania koni spoczywał na najbogatszych (plousiotatoi), którzy za czasów Agesilaosa II przekazywali konie i uzbrojenie jeźdźcom dopiero w momencie ogłoszenia wojny. Niska jakość spartańskiej jazdy wynikała nie tylko z tego, że służbę w tej formacji uznawano za najmniej zaszczytną i rekrutowano do niej ludzi najsłabszych pod względem fizycznym (somasin adynatotatoi) i najmniej ambitnych (hekista philotimoi), jak twierdzi Ksenofont ${ }^{23}$, ale być może także z tego względu, że zamożni Spartanie, chcąc ograniczyć wydatki, dostarczali konie niskiej wartości. W efekcie w spartańskiej jeździe służyli niedoświadczeni żołnierze (sposób rekrutacji uniemożliwiał doskonalenie sztuki jeździeckiej w czasie pokoju) na słabych koniach. Nie dziwi, że nie mogła się ona równać z kawalerią innych państw. Znamienny jest fakt, że spartańscy hodowcy łożyli znacznie więcej na hodowlę „nieobowiązkowych” koni wyścigowych niż „obowiązkowych” bojowych. Świadczy o tym z jednej strony słabość spartańskiej jazdy, a z drugiej - liczba spartańskich zwycięstw w agonach hippicznych.

Co do ras koni, w kontekście Sparty słyszymy o rasach eneckiej

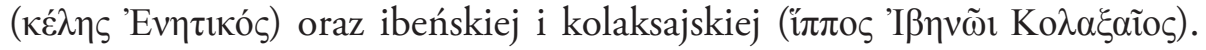
Obie wzmianki pochodzą z Partheneionu Alkmana (wiersze 51 i 59). Konie eneckie wywodziły się z azjatyckiej Paflagonii albo adriatyckiego Veneto w północnych Włoszech, regionów słynących z hodowli koni ${ }^{24}$. To właśnie dzięki koniom eneckim laur olimpijski zdobył Leon, jak zaświadcza cyto-

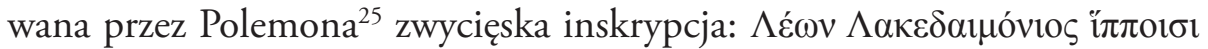

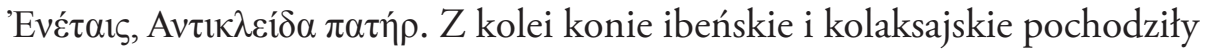

22 Thuk. 4, 55.

23 Hell. 6, 4, 11. Por. ibidem 3, 4, 15.

24 G. Devereux, The Enetian Horses of Euripides, Hippolytos 231, 1131, „L'Antiquité Classique" 1964, t. 33, s. 375-383; idem, The Enetian Horse of Alkman's Partheneion, „Hermes” 1966, t. 94, nr 2, s. 129-134; K. Tsantsanoglou, Of Golden Manes and Silvery Faces: The Partheneion 1 of Alcman, Berlin 2012, s. 51-53.

25 Fragmenta Historicorum Graecorum 3, 122. 
odpowiednio z Lidii i Scytii ${ }^{26}$. Niewiele możemy powiedzieć o ich wartości, poza tym, że ibeńskie, jak wynika z Partheneionu, uchodziły za lepsze od kolaksajskich. Konkretne kwoty padają wyłącznie w kontekście pozaspartańskim ${ }^{27}$. I tak Bucefał, koń bojowy Aleksandra Wielkiego, miał kosztować 13 talentów ${ }^{28}$; Ksenofont podczas swojej anabazy, gdy brakło mu pieniędzy, sprzedał konia, za którym przepadał, za 50 darejków, ekwiwalent 12,5 miny $^{29}$; Strepsjades za dobrego konia wyścigowego „z kappą” (koppatias) zapłacił 12 min $^{30}$; wedle Izajosa ${ }^{31}$ Dikaiogenes nigdy nie był prawdziwym hodowcą koni, ponieważ w swoim majątku nie posiadał ani jednego konia, którego wartość przekraczałaby 3 miny. Jeśli odrzucimy podejrzaną cenę Bucefała, cena dobrego konia, zarówno wyścigowego, jak i bojowego, oscylowała w epoce klasycznej wokół 10 min (Ksenofont, wielki znawca koni i dowódca wojskowy, musiał podczas wyprawy wojennej dosiadać konia bardzo dobrej jakości, a okoliczności sprzedaży wskazują, że 50 darejków było ceną zaniżona); za konia przeciętnej jakości płacono nie więcej niż 3 miny.

Cena samego wozu z kołami (diphriskos kai trochoi) dochodziła do 3 min w Atenach doby wojny peloponeskiej32, zaś koszt czterokonnego zaprzęgu z końmi najlepszej jakości $-5^{33}$ albo $8^{34}$ talentów. Taką sumę pieniędzy miał wręczyć Alkibiadesowi w 416 roku p.n.e. żądny zwycięstwa olimpijskiego przyjaciel, aby ten, korzystając ze swoich wpływów, zakupił publiczny zaprzęg w Argos (nie tylko osoby prywatne, ale także państwa miały możliwość uczestnictwa w igrzyskach olimpijskich, a Argos miało już sukcesy na tym polu, zyskując laur w 472 roku p.n.e. $)^{35}$. Alkibia-

26 G. Devereux, The Kolaxaian Horse of Alkman's Partheneion, „Classical Quaterly” 1965 , t. 15, nr 2, s. 176-184; K. Tsantsanoglou, op. cit., s. 59-62.

27 J.K. Anderson, op. cit., Berkeley \& Los Angeles 1961, s. 136-137; J.H. Kroll, An Archive of the Athenian Cavalry, „Hesperia” 1977, t. 46, nr 2, s. 88-89.

28 Gell. 5, 2.

29 Xen. An. 7, 8, 6; ibidem 1, 5, 6: 1 darejka = 25 drachm.

30 Ar. Nub. 21-23.

31 Isae. 5, 43.

32 Ar. Nub. 31.

33 Isok. 16, 46.

34 Diod. 13, 74, 3.

35 POxy 2, 222; A 129. 
des nabył argiwski tethrippon, ale nie przekazał go przyjacielowi, lecz pod swoim nazwiskiem wystawił w Olimpii i zwyciężył, co doprowadziło do skandalu i procesu ${ }^{36}$. Jest to jedyna wzmianka na temat wartości pieniężnej tethripponu, którą dysponujemy, i nawet jeśli jego cena była znacznie zawyżona z uwagi na okoliczności (wszystko wskazuje na to, że Alkibiades kupił zaprzęg tuż przed igrzyskami, w których Argos, jako państwo, miało zamiar wziąć udział), dysproporcja cen jest uderzająca. Nabywca bowiem czterech dobrych koni wyścigowych i wozu po cenach z "Chmur” Arystofanesa zapłaciłby $51 \mathrm{~min}$, a więc prawie sześć (lub ponad dziewięć) razy mniej niż Alkibiades. Różnicę tę tłumaczą koszty i czasochłonność treningu, którym poddawane były konie. $\mathrm{Na}$ jego temat nie znajdujemy wiele informacji nawet w „Sztuce jeździeckiej” Ksenofonta, która nie porusza tematyki związanej z wyścigami rydwanów, skupiając się raczej na koniach bojowych, co podkreśla sam autor $(1,2$ i 3, 7). Z kolei materiał archeologiczny nie jest instruktywny, ponieważ w większości wypadków przedstawia zwierzęta już wyszkolone $^{37}$. Powyższa dysproporcja cenowa wskazuje wyraźnie, że sukces w wyścigach konnych zależał znacznie bardziej od biegłości w sztuce powożenia i ułożenia rumaków niż od ich szybkości.

Poza kosztami zakupu koni i wozu właściciel zaprzęgu ponosił wydatki związane z żywieniem i utrzymaniem całej infrastruktury potrzebnej do prowadzenia hippicznego przedsięwzięcia. Obliczono (wychodząc od świadectw antycznych ${ }^{38}$, a kończąc na racjach żywieniowych przyznawanych brytyjskiej kawalerii na początku XX wieku), że koń bojowy konsumował przeciętnie 4 chojniksy (około $3 \mathrm{~kg}$ ) jęczmienia dziennie, co w wypadku czterech koni dawałoby $4380 \mathrm{~kg}$ rocznie (koń wyścigowy z uwagi na duży wysiłek spożywał zapewne jeszcze więcej). W pierwszej połowie XX wieku wyprodukowanie takiej ilości zboża w Lakonii i Messenii wymagało obsiania niemal 7 ha pól uprawnych, co w porównaniu ze średnią wielkością greckiego gospodarstwa hoplickiego $(3,6-5,4$ ha) pokazuje mimo

36 Isok. 16, 1 nn.; Diod. 13, 74, 3-4; Plut. Alk. 12, 3. Zob. D. Gribble, Alcibiades at the Olympics: Performance, Politics and Civic Ideology, „The Classical Quarterly” 2012, t. 62, nr 1, s. 45-71.

37 M.B. Moore, Horse Care as Depicted on Greek Vases before 400 B. C., „Metropolitan Museum Journal” 2004, t. 39, s. 52-53.

38 Plb. 6, 39, 13-14. 
wszelakich zastrzeżeń skalę wydatków ${ }^{39}$. Prowadzenie hodowli koni wymagałoby przynajmniej dwukrotnie większego areału ziemi.

Co do infrastruktury, poza przeznaczeniem części gruntów pod uprawę zboża na paszę właściciel koni musiał wydzielić część terenów także pod wypas. Ich wielkość zależała od strategii związanej z hippotrophią. Grecki termin jest szeroki i obejmuje zarówno wieloletnich hodowców koni, jak i posiadaczy pojedynczych zaprzęgów lub koni, choć naturalnie Grecy dostrzegali różnice majątkowe dzielące jednych i drugich ${ }^{40}$. Tak więc Spartanin z ambicjami jeździeckimi mógł zadowolić się zakupem zaprzęgu i ponosić niezbędne wydatki związane z jego utrzymaniem, jak było zapewne w wypadku Euagorasa, który tą samą czwórką koni zdobył trzy wieńce olimpijskie $^{41}$, albo rozwinąć hodowlę niekiedy przechodzącą z ojca na syna, jak rzecz się miała z Damononem i Enymakratidasem. W przypadku drugiej opcji ilość ziem oddawanych pod pastwiska musiała być znacząco większa. Zachowały się dwa świadectwa potwierdzające taką praktykę. W pierwszym skalista Itaka, kraj kóz, zostaje przez Telamacha przeciwstawiona Sparcie Menelaosa, widzianej jako kraj koni: równinny, bogaty w pola orne i pastewne, opatrzony takimi epitetami, jak hippobotos, „obfitujący w pastwiska dla koni”, oraz hippelatos, „nadający się do jazdy konnej” ${ }^{2}$. W drugim Sokrates stwierdza, że żaden majątek ateński nie może się równać ze spartańskimi ani pod względem rozległości i jakości ziem, ani pod względem ilości pracujących na nim niewolników, ani wreszcie mnogości koni i trzody (boskemata) wypasanej w Messenii ${ }^{43}$. Oba świadectwa zgodnie charakteryzują Lacedemon jako krainę hodowców koni. Później, w czasach Kleomenesa III, z Messenii wywodzić się będą handlarze zawodowo parający się sprzedażą koni, jak niejaki Nikagoras z Meseny, podróżujący w tym celu (z końmi bojowymi) do Egiptu ${ }^{44}$.

O elitarnym, kosztownym charakterze hippotrophii świadczy także wyjątkowe jak na realia greckie prawodawstwo spartańskie co do sposobu

\footnotetext{
39 Obliczeń dokonał S. Hodkinson, op. cit., s. 314-315.

40 Isae. 5, 43.

41 Hdt. 6, 103.

42 Hom. Od. 601-608.

43 Pl. Alk. I 122D.

44 Plut. Kleom. 35, 3.
} 
użytkowania koni przez członków wspólnoty obywatelskiej. Otóż Ksenofont pisze, że Likurg zaprowadził w Sparcie wspólnotę (koinonia) korzystania z koni (podobnie jak z niewolników i psów myśliwskich, choć na innych zasadach): „Gdy ktoś zachoruje albo potrzebuje wozu lub chce szybko dokądś dotrzeć, a zobaczy gdzieś konia, może go wziąć i skorzystać, a potem odstawić z powrotem w dobrym stanie" ${ }^{45}$. O zwyczaju tym wspominają także Arystoteles ${ }^{46}$ i Plutarch ${ }^{47}$, jednak bez podania okoliczności, które pozwalały Spartiatom korzystać z koni swoich współobywateli. Istnienie takiego prawa jasno wskazuje, że nie każdy obywatel mógł pozwolić sobie na posiadanie koni. Ich pożyczanie wraz z wozem bez konieczności uzyskania uprzedniej zgody właściciela było możliwe tylko w sytuacjach wyjątkowych. Co prawda Ksenofont wspomina jedynie o stanie zagrożenia życia (możliwość ta wpisuje się w szerzej zakrojoną troskę państwa o zachowanie jak najliczniejszego grona obywateli), ale można domyślać się, że w rachubę wchodziły także wszelkie sprawy wagi państwowej. Zupełnie nie wiemy, co w sytuacji, gdyby koń został odstawiony w stanie „niedobrym”.

Naturalnie hodowla koni, pomimo olbrzymich kosztów, niekoniecznie musiała być jedynie obciążeniem finansowym. Bardzo prawdopodobne, że hodowcy mieli zyski ze sprzedaży współobywatelom części koni ze swojej stadniny. Z kolei zwycięzcy w hippikoi agones otrzymywali nagrody, ale w przypadku Olimpii, Delf, Nemei i Istmu o raczej znikomej wartości materialnej; co innego z igrzyskami panatenajskimi, w których zwycięzcy w wyścigu dwukonnych zaprzęgów (synoris) otrzymywali 140 amfor oliwy o wartości 1680-2520 drachm (nie znamy nagród dla tethrippa; nagroda w tej samej konkurencji na Małych Panatenajach, dostępnych tylko dla Ateńczyków, wynosiła amfor 30). Należy jednak pamiętać, że ślady spartańskiego uczestnictwa w Wielkich Panatenajach urywają się u schyłku epoki archaicznej, a więc około wieku przed datą inskrypcji informującej o wysokości nagród w agonach panatenajskich, i jako takie mogą służyć

45 Lak. Pol. 6, 3, tłum. A. Zinkiewicz, A.R. Sypuła, J. Longfors, M. Daszuta pod kier. R. Kuleszy.

46 Pol. 1263A.

47 Inst. Lak. 238E-F. 
jedynie za wskazówkę ${ }^{48}$. W świetle powyższych uwag jasne jest zatem, że to nie chęć zysku finansowego kierowała spartańskimi hodowcami i sportowcami. Główną rolę odgrywał tu prestiż.

Szczególnie instruktywny w tym kontekście jest komentarz Izokratesa ${ }^{49}$, syna Alkibiadesa, wyjaśniający, dlaczego ojciec w 416 roku p.n.e. wystawił na igrzyskach olimpijskich aż siedem tethripponów. Po pierwsze, Alkibiades wziął udział w zawodach olimpijskich, ponieważ cieszyły się one uznaniem i podziwem u wszystkich Greków; po drugie, dzięki zwycięstwom mógł przysporzyć chwały nie tylko sobie, ale i własnej ojczyźnie, zaś po trzecie, że za współzawodników w wyścigach rydwanów miał równych sobie. Hippotrophia bowiem „była zajęciem dla najbogatszych (eudaimonestaton), całkiem niedostępnym dla biednych" w przeciwieństwie do agonów gymnicznych, do których dostęp mieli także „ludzie niskiego rodu, pochodzący z małych mieścin i słabego wykształcenia”. Bardzo możliwe, że podobnymi pobudkami kierowali się spartańscy hodowcy koni i podobnie jak inni dążyli do upamiętnienia swoich sukcesów. W VI księdze „Wędrówek po Helladzie" Pauzaniasza można odnaleźć informacje o pomnikach, które olimpionicy spartańscy w tethripponie wystawili w Olimpii ${ }^{50}$. Pierwsze dwa pomniki (Euagorasa i Polypeithesa) przedstawiały jedynie rydwan, późniejsze, począwszy od połowy $\mathrm{V}$ wieku p.n.e., postać samego zwycięzcy, bez rydwanu (Arkesilaos, Leon, Ksenarkes, Anaksandros, Lichas i Lykinos); jednak dwa z nich wyróżniały się okazałością. Pierwszy należał do Polyklesa, triumfatora nie tylko w Olimpii (w 440 lub 424 roku p.n.e.), ale także w Delfach, Nemei i na Istmie, który, w związku z licznymi zwycięstwami i posagami wystawionymi dla ich uczczenia, otrzymał przydomek Polychalkos, „bogaty w brąz” lub „zrobiony z brązu”. Tak opisywał jego pomnik Pauzaniasz: „Posąg ma w prawej ręce opaskę (tainia) do włosów. Przy nim dwaj chłopcy (paidia). Jeden trzyma w ręku koło (trochos), drugi prosi o przepaskę" ${ }^{51}$. Dwaj chłopcy to prawdopodobnie synowie Polyklesa, koło - symbol

48 S. Hodkinson, op. cit., 316-317.

49 Isok. 16, 32-33.

50 Ogólnie o pomnikach zob. W.W. Hyde, Olympic Victor Monuments and Greek Athletic Art, Washington 1921, s. 264-272, szczegółowo S. Hodkinson, op. cit., s. 319-323.

51 Paus. 6, 1, 7-8, tłum. J. Niemirska-Pliszczyńska. 
wozu, zaś gest sięgnięcia po przepaskę należy interpretować jako zapowiedź przyszłych sukcesów następców Polyklesa. Drugi pomnik wystawiła Kyniska, siostra Agesilaosa, a przedstawiał on „rydwan zaprzężony w cztery konie, woźnicę, a wreszcie posąg Kyniski” na bazie marmurowej ${ }^{52}$. Kyniska złożyła w darze wotywnym także inny pomnik na pamiątkę swojego zwycięstwa, który to znajdował się w przedsionku świątyni Zeusa w Olimpii i przedstawiał konie „nieco mniejsze od prawdziwych” 53 .

Poza wystawieniem pomnika w Olimpii zwycięzca celebrował swoje sukcesy (epinikia), składając zwycięską ofiarę (taepinikia thyein), wyprawiając zwycięską ucztę (ta epinikia estian) i wysłuchując zwycięskiej pieśni (epinikioi aoidai lub po prostu epinikia) ${ }^{54}$. Żadna z takich pieśni nie zachowała się do naszych czasów (o ile istniały). Dysponujemy jednak treścią niektórych inskrypcji umieszczonych na pomnikach olimpijskich, które dają świadectwo stosunku spartańskich olimpioników do swoich zwycięstw. Większość napisów na pomnikach zawierała imię, ojczyznę i konkurencję zwycięzcy, jednak niektóre zostały zaopatrzone w informacje dodatkowe, najczęściej odnoszące się do pochodzenia i podkreślające sportowe tradycje rodziny. Tak było w wypadku Arkesilaosa i jego syna Lichasa, którzy zdobyli laur w tethripponie ${ }^{55}$; Anaksandrosa, chwalącego się, że jako pierwszy w rodzie uzyskał tytuł olimpionika na rydwanach i zaraz dodał, że wcześniej jego dziadek zwyciężył w pięcioboju ${ }^{56}$; oraz Polypeithesa, co w Olimpii postawił niewielki pomnik w postaci rydwanu i na tej samej kolumnie, na której stał rydwan, kazał umieścić posag ojca, Kallitelesa, mistrza olimpijskiego w zapasach ${ }^{57}$. Wszystkie te informacje Pauzaniasz odczytywał z inskrypcji. Najsłynniejsza jednak pozostaje inskrypcja Kyniski. O samej Kynisce nic

52 Ibidem 6, 1, 6 .

53 Ibidem, 5, 12, 5.

54 B. Currie, Epinician Choregia: Funding a Pindaric Chorus, w: Archaic and Classical Choral Song: Performance, Politics and Dissemination, red. L. Athanassaki, E. Bowie, Berlin 2011, s. 263.

\footnotetext{
55 Paus. 6, 2, 1-2.

56 Ibidem, 6, 1, 7.

57 Ibidem, 6, 16, 6.
} 
pewnego nie wiemy poza tym, że była rodzoną siostrą Agesilaosa II ${ }^{58}$. Na tej podstawie można przypuszczać, że w momencie sukcesu w Olimpii miała między 40 a 50 lat $^{59}$. Poniżej treść inskrypcji ${ }^{60}$.

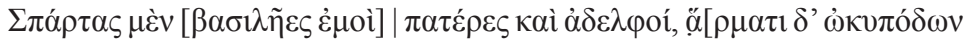

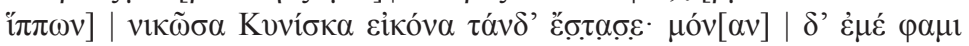

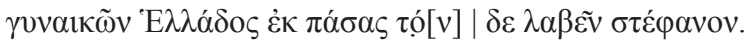

Sparty królowie moimi | są ojcami i braćmi. Zaprzęgiem o szybkonogich koniach | odniósłłzy zwycięstwo, Kyniska pomnik ten wystawiła. | Twierdzę, że jestem jedyną w całej Helladzie kobietą, | która po ten wieniec sięgnęła (tłum. własne).

Trzech autorów antycznych wypowiada się w sprawie okoliczności jej niezwykłego sukcesu. Ksenofont, wychwalając Agesilaosa, powiada, że hodował on wiele psów myśliwskich i koni bojowych (hippoipolemisterioi), swoją siostrę natomiast „namówił, aby hodowała konie wyścigowe (harmatotrophein) i wykazał dzięki jej zwycięstwu, że nie jest to oznaką męstwa (andragathia), lecz bogactwa (plutos)" 61 . W podobnym tonie przedstawia sprawę Plutarch. Pisze on, że Agesilaos postanowił namówić Kyniskę do wzięcia udziału w igrzyskach, widząc, jak niektórzy obywatele spartańscy wielce chełpili się hippotrophią i przewagami, jakie miała dawać, tymczasem jej zwycięstwo miało pokazać nie tylko im, ale wszystkim Grekom, że nie wynikało ono wcale z cnoty osobistej (arete), ale przewagi majątkowej (plutos) i poniesionych wydatków (dapane $)^{62}$. Nieco inaczej ujmuje rzecz Pauzaniasz. Nie wspomina słowem o Agesilaosie, a samą Kyniskę przedstawia

58 P. Poralla, Prosopographie der Lakedaimonier bis auf die Zeit Alexanders des Grossen, Breslau 1913, s. 79.

59 D. Kyle, "The Only Woman in All Greece": Kyniska, Agesilaus, Alcibiades and Olympia, „Journal of Sport History" 2003, t. 30, nr 2, s. 184.

${ }^{60}$ Inscriptiones Graecae V, 1, 1564 A; Anth. Pal. 13, 16.

${ }^{61}$ Ages. 9, 6, tłum. M. Daszuta, R. Matuszewski, T. Makólski-Świercz, J. Wawrowski, A.M. Kruszyńska, M. Myszkowska-Kaszuba pod kier. R. Kuleszy.

${ }^{62}$ Ages. 20, 1 = Plut. Lak. Apophth. 212B. 
jako kobietę, która „jak najżarliwiej zapragnęła odznaczyć się (philotimotata) w zawodach olimpijskich"63.

Motywy, dla których Kyniska rozpoczęła hodowlę koni i wzięła udział w igrzyskach olimpijskich, były zatem dwa: po pierwsze, jej ambicja i chęć okrycia się chwałą (philotimia); po drugie - chęć zdyskredytowania przez Agesilaosa aktywności, jaką była hodowla koni wyścigowych. Ta walka z hodowlą koni wyścigowych polegała z jednej strony na przedstawieniu jej jako zajęcia właściwego dla kobiet ${ }^{64}$ (u Ksenofonta widać silne przeciwstawienie „męskiej” hodowli psów myśliwskich i koni bojowych oraz „żeńskiej” hodowli koni wyścigowych), a z drugiej na uznaniu jej za aktywność, która nie wymagała i nie pielęgnowała cnoty, a była tylko pochodną bogactwa. Innymi słowy, Agesilaos w swojej propagandzie operował dwoma parami przeciwieństw: męskie-żeńskie oraz cnota-bogactwo, dając do zrozumienia, że właściwym wyborem dla mężczyzny jest droga cnoty, wyrażającej się w podejmowaniu aktywności pożytecznych z perspektywy państwa, a zwłaszcza przydatnych na wojnie (stąd łowiectwo i hodowla koni bojowych), a nie tych, które żadnego przełożenia na dobro polis i wojnę nie mają. Tego typu zajęcia, wymagające jedynie majątku bez powiązania z cnotą, należy zostawić kobietom. Bogactwo jest wartością tylko o tyle, o ile służy wspólnocie, a nie jest przeznaczane na tak osobiste aktywności, jak harmatotrophia. To jeszcze jedna para przeciwieństw: publiczne-prywatne, widoczna w argumentacji Agesilaosa. Rację ma Jean Ducat ${ }^{65}$, pisząc, że należy podchodzić ostrożnie do tego moralizatorskiego i - dodajmy silnie retorycznego przekazu. Zwróćmy przy tym uwagę, że ów atak w hodowców koni wyścigowych, których w wyniku napływu bogactw do Sparty po wojnie peloponeskiej musiało przybywać, jako świadectwo konfliktu króla z przedstawicielami elity majątkowej, dowodzi raczej ich siły politycznej, a nie kobiecości. Właśnie tak należy odczytywać wzmiankę Plutarcha o pewnej grupie obywateli, którzy budowali swoją pozycję, poczucie wartości i kapitał polityczny na podstawie hippotrophii.

63 Paus. 3, 8, 1, tłum. J. Niemirska-Pliszczyńska.

64 S. Hodkinson, op. cit., s. 327.

65 J. Ducat, La fermme de Sparte et la guerre, „Pallas. Revue d'études antiques” 1999, t. 51, s. 168 . 
Inna sprawa, że wyjaśnianie przez Ksenofonta, a za nim przez Plutarcha, motywacji Agesilaosa chęcią udowodnienia współobywatelom, a nawet wszystkim Grekom, że pewne aktywności są oparte na cnocie, a inne jej nie wymagają, wykazuje pewną słabość. Bowiem gdyby w istocie szło jedynie o wykazanie, że hodowla koni wyścigowych i sukces w hippikoi agones nie ma związku z cnotą, dlaczego Agesilaos nie zadowolił się udowodnieniem swoich twierdzeń w 396 roku p.n.e., kiedy Kyniska po raz pierwszy sięgnęła po wieniec olimpijski, i namawiał ją do powtórzenia wyczynu (z sukcesem) na kolejnych igrzyskach w roku 392 p.n.e.? Aby wzmocnić przekaz, zamknąć usta powątpiewającym czy jeszcze z jakiegoś innego powodu? Znacznie bardziej prawdopodobne wydaje się założenie, że zwyczajnie nie musiał Kyniski do niczego namawiać ${ }^{66}$. To, jak się wydaje, sugeruje Pauzaniasz, podkreślając jej wielką ambicję. Niemniej sprawa wpływu Agesilaosa na Kyniskę nie jest jasna. Jedni widzą ją w roli marionetki w rękach brata ${ }^{67}$, inne głosy wskazują na jej niezależność ${ }^{68}$, a nawet podkreślają buntownicze nastawienie wobec Agesilaosa ${ }^{69}$. Z pewnością rację ma Ellen Millender ${ }^{70}$, kiedy pisze, że materiał źródłowy nie pozwala na definitywne rozstrzygnięcia w tej kwestii, ale nic nie stoi na przeszkodzie, aby uznać, że cele Agesilaosa i philotimia Kyniski nie tylko się nie wykluczały, ale uzupełniały ${ }^{71}$. Kyniska z pewnością wykazywała inicjatywę, nawet jeśli pomysłodawcą całego przedsięwzięcia był Agesilaos. Wskazuje na to z jednej strony okazałość monumentu, który przewyższał wszystkie inne spartańskie pomniki w Olimpii, a z drugiej treść napisu, który kazała umieścić na pomniku. W żaden sposób nie licuje on z ideologią obywatelską oficjalnie propagowaną przez

${ }^{66}$ R. Kulesza, Wstęp, [w:] Ksenofont, Agesilaos, przekł. pod kier. R. Kuleszy, „Akme. Studia Historica" 2014, t. 12, s. 25.

${ }^{67}$ P. Cartlegde, Agesilaos and the Crisis of Sparta, London 1987, s. 149-150; D.R. Shipley, Plutarch's Life of Agesilaos: Response to Sources in the Presentation of the Character, Oxford 1997, s. 247-248; A. Powell, op. cit., s. 231; E.G. Millender, Spartan Women, [w:] A Companion to Sparta, red. A. Powell, t. 2, Chicester 2018, s. 515-516.

${ }_{68}$ R. Kulesza, op. cit., s. 24-25.

69 S. Pomeroy, op. cit., s. 22-23, 76.

${ }^{70}$ E.G. Millender, op. cit., s. 517.

71 D. Kyle, Sport and Spectacle in the Ancient World, Chicester 2015, s. 185. 
Agesilaosa $^{72}$, podkreślając wielką wagę historyczną dokonań Kyniski oraz jej indywidualizm, uwypuklony przez silne pierwszoosobowe zdania: to „ja”, Kyniska; „ja” twierdzę; „ja” jako jedyna spośród kobiet ${ }^{73}$. Treść napisu to jedno, a jego forma - drugie. Periegeta ${ }^{74}$ stwierdza bowiem, że poza Pauzaniaszem, słynnym zwycięzcą spod Platei, dla którego epigram wyryty na trójnogu wotywnym złożonym w Delfach ułożył Simonides z Keos, i właśnie Kyniski, żaden król (a co za tym idzie - Spartiata) nie posługiwał się kompozycją poetycką. Dobrze oddaje to ambicje Kyniski. Paul Cartlegde ${ }^{75}$ trafnie zauważa, że Agesilaos musiał podejrzliwie podchodzić do tonu epigramu i bez wątpienia potępić przepych pomnika, przynajmniej oficjalnie. Niewykluczone, że jeśli chciał posłużyć się Kyniską, to w pewnym momencie oswobodziła się ona spod jego wpływów.

Uczeni wskazują także na inne motywy, które mogły powodować Agesilaosem i Kyniską. Ich bezpośrednich śladów w źródłach jednak nie znajdziemy. Paul Cartledge ${ }^{76}$ zasugerował, że Agesilaos chciał wykorzystać chwałę pochodzącą ze zwycięstwa olimpijskiego Kyniski dla celów swojej panhelleńskiej propagandy związanej z planowaną wyprawą na Persję. Myśl tę podjęła Ellen Millender ${ }^{77}$, która obydwa zwycięstwa olimpijskie Kyniski wiąże z zaangażowaniem Agesilaosa na Wschodzie. Otóż sukces Kyniski w 396 roku p.n.e., zbiegający się z początkiem wyprawy przeciw Persji, miał wzmocnić wizerunek Agesilaosa, przedstawiając go jako panhellena faworyzowanego przez bogów i obdarzonego rysami heroicznymi, które idealnie predestynowałyby go do roli przywódcy wyprawy wojennej. Natomiast zwycięstwo z 392 roku p.n.e. miałoby być czymś w rodzaju wytchnienia dla Agesilaosa i Spartan po niedawnych porażkach militarnych i politycznych ${ }^{78}$

72 C. Fornis, Cynisca l'Eurypontide: genre, autorité et richesse dans la Sparte impériale du début du ive siècle avant notre ère, [w:] Dossier: Des vases pour les Athéniens : viè-iv siècle avant notre ère, Paris 2014, s. 320.

73 L.G. Mitchell, The Women of Ruling Families in Archaic and Classical Greece, „The Classical Quarterly” 2012, t. 62, nr 1, s. 17.

74 Paus. 3, 8, 2.

75 P. Cartledge, op. cit., s. 150.

76 Ibidem.

77 E. Millender, op. cit., s. 515-516.

78 Xen. Hell. 4, 4, 1-6; Diod. 14, 86, 1 i 14, 92, 1. 
oraz wezwaniem kierowanym do innych Greków do utrzymania panhelleńskiej solidarności w ich obliczu, a zarazem potwierdzeniem prawa Agesilaosa do kontynuowania antyperskiej kampanii. Argumenty te zasługują na uwagę. Zwycięstwo olimpijskie było zawsze powodem do chwały, nie tylko dla samego olimpionika, ale także jego rodu oraz ojczyzny. Dobrze o tym świadczą spartańskie (i nie tylko) inskrypcje, które zwycięzcy kazali ryć na swoich pomnikach w Olimpii, oraz mowa Izokratesa wspominana wyżej. Także w 392 roku p.n.e. tocząca ze zmiennym powodzeniem wojnę koryncką Sparta mogła potrzebować sukcesu utwierdzającego jej ambicje do hegemonii w świecie greckim. Niemniej wizja ta może wykazywać pewną sprzeczność z przekazem Ksenofonta (a za nim Plutarcha), który jako przyjaciel i współpracownik Agesilaosa przedstawia propagandę króla spartańskiego w czystej postaci. Celem Agesilaosa było wszak przeciwdziałanie hodowli koni wyścigowych oraz udziałowi w hippikoi agones, a ściślej uderzenie w spartańskich oligarchów. Czy więc Agesilaos uprawiał zręczną gimnastykę na polu propagandy, aby jednocześnie dyskredytować harmatotrophię i czerpać z niej korzyści polityczne? Myślę, że tak. Środkiem do tego było zaangażowanie w przedsięwzięcie Kyniski, dzięki której pod pozorem walki o cnotę mógł zbijać kapitał polityczny, przy okazji zaspokajając jej wielką ambicję.

Można także przedstawić wizję, w której Agesilaos nie miał wpływu na poczynania siostry. Kyniska, jak słusznie zauważa César Fornis ${ }^{79}$, była kobietą swoich czasów, które charakteryzowały się postępującym odchodzeniem obywateli od ideałów likurgowych w następstwie zwycięstwa w wojnie peloponeskiej. Tendencje te najsilniejsze były pośród najzamożniejszych, którzy realizowali swoje ambicje, marnotrawiąc (w opinii Agesilaosa) potężne środki na hodowlę koni wyścigowych. Tragedią Agesilaosa miałby być fakt, że jego własna siostra również uległa owej „pustej” żądzy zaszczytów, którą przejawiali jego przeciwnicy polityczni. Ksenofont jako apologeta i piewca Agesilaosa starał się to zatuszować i przedstawić poczynania Kyniski jako zgodne z wizją brata i całkiem od niego zależne. Niemniej Kyniska nie odcina się od brata w swoim epigramie, wręcz przeciwnie, wspomina go i swojego ojca (obu co prawda bezimiennie), przedstawiając

79 C. Fornis, op. cit., s. 317. 
tym samym zwycięstwo jako powód do dumy dla rodu Eurypontydów. Poza tym trudno wyobrazić sobie, by Kyniska mogła działać całkowicie wbrew intencjom brata, który najpierw w sposób bezwzględny pozbawił wraz z Lizandrem praw do tronu Leotychidasa, a później niewdzięcznie (tę niewdzięczność Ksenofont naturalnie pomija milczeniem) rozprawił się z samym Lizandrem ${ }^{80}$. Zdaje się, że działania Kyniski nie tylko miały przynajmniej ciche poparcie Agesilaosa, ale także sankcję wspólnoty. Upamiętnienie zwycięstwa nie ograniczyło się wszak wyłącznie do Olimpii. W pobliżu Platanistas, samym centrum Sparty, wybudowany został przybytek (heroon) heroizowanej Kyniski, najprawdopodobniej już po jej śmierci ${ }^{81}$. Według Jeana Ducata ${ }^{82}$ bliskość dromosu, miejsca, w którym dziewczęta biegały, świątyni Heleny, stanowiącej „model dla młodej Spartanki”; i grobu Alkmana, wychowawcy dziewcząt, dowodzi, że Kyniska miała stanowić wzór i przykład dla młodych Spartanek jako ta, która osiągnęła doskonałość (aristeia). Kyniska z pewnością przetarła szlak. Pauzaniasz ${ }^{83}$ powiada, że w jej ślady poszło wiele innych kobiet, szczególnie z Lacedemonu. Żadna jednak z nich nie zyskała takiej sławy, a w zasadzie słyszymy tylko o jednej Spartance, Euryleonis, zwyciężczyni olimpijskiej w synoris z 368 roku p.n.e., która podobnie jak poprzedniczka zadbała o okazałe uhonorowanie sukcesu, stawiając własny posąg w pobliżu świątyni Ateny Chalkioikos ${ }^{84}$. Oba przypadki należą do wyjątkowych, gdyż żaden inny olimpionik w agonach hippicznych nie uzyskał podobnego wyróżnienia w samym mieście. Wymowny znak nowych czasów.

Ryszard Kulesza ${ }^{85}$ zwraca uwagę, że Ksenofont pomija milczeniem jeszcze jedną sprawę. Otóż wystawienie tethripponu w Olimpii przez kobietę i wzięcie przez nią pierwszej nagrody było zapewne szokiem dla Greków.

80 Zob. Xen. Hell. 3, 4, 7-10 i 4, 4, 9; Arist. Pol. 1301B; Diod. 14, 13, 2 i 8; Plut. Lys. 24-26; Plut. Ages. 8, 1; Nep. Lys. 3.

81 Paus. 3, 15, 1.

82 J. Ducat, op. cit., s. 168; pace S. Hodkinson, op. cit., s. 328 i C. Fornis, op. cit., s. 322 .

83 Paus. 3, 8, 1.

84 Ibidem 3, 17, 6.

85 J. Ducat, The Women of Sparta, „Anabasis: Studia Classica et Orientalia” 2013, t. 4, s. 23. 
Niektórym wyczyn ten z pewnością się nie podobał i mógł stać się podstawą do wysunięcia zarzutów przeciwko jej bratu, który nie potrafil przeciwdziałać zepsuciu toczącym Spartę i jako taki był odpowiedzialny za jej upadek. Arystoteles, piszący o gynaikokratii czy silnej pozycji majątkowej kobiet spartańskich ${ }^{86}$ i upatrujący w nich przyczyny końca Sparty, zapewne miał w pamięci wyczyny Kyniski, Euryleonis i innych nieznanym nam Spartanek. Czy nie o nich myśli, twierdząc, że w okresie panowania Sparty w Grecji, a więc dokładnie za ich i Agesilaosa życia, „kobiety wywierały wielki wpływ na rządy"? ${ }^{87}$ Czy przekroczenie przez Kyniskę granic dzielących świat mężczyzn i kobiet w 396 roku p.n.e. nie jest jaskrawym przykładem niezdyscyplinowania (anesis), które przedstawia jako cechę charakterystyczną Spartanek?88 Bez wątpienia pokrętne wyjaśnienia Ksenofonta, który w całym „Agesilaosie” ma manierę odpierania niewyartykułowanych zarzutów stawianych swojemu bohaterowi po Leuktrach, w istocie mają na celu oczyścić jego reputację. Ten szok wynikał nie tylko z tego, że kobieta wkroczyła w świat zarezerwowany dotychczas dla mężczyzn, ale także stąd (i to miało, jak sądzę, kluczowe znaczenie i musiało budzić największe zdumienie), że w tym męskim świecie okazała się lepsza od mężczyzn. Wyobrażam sobie, że zaraz po sięgnięciu po laur przez Kyniskę jej zwycięstwo zostało przedstawione jako wielki tryumf Sparty, która wydała na świat i wychowała kobietę lepszą od najwybitniejszych mężczyzn Grecji. Czy to nie dowód wyjątkowości i przewagi Sparty, która słusznie przewodziła w Helladzie po wojnie peloponeskiej? Takiej interpretacji Ksenofont nie mógł jednak nawet zasugerować w „Agesilaosie” napisanym po $371 \mathrm{roku}$ p.n.e. Czas bowiem brutalnie dla Sparty ją zweryfikował.

86 Pol. 1269B-1270A.

87 Ibidem 1269B.

${ }^{88}$ Ibidem. Na temat anesis, lecz bez powiązania z działalnością Kyniski, zob. J. Redfield, The Women of Sparta, „The Classical Journal” 1978, t. 73, nr 2, s. 148-150; P. Cartledge, Spartan Wives: Liberation or Licence?, „The Classical Quarterly” 1981, t. 31, nr 1, s. 87-88; L. Thommen, Sparta Verfassungs- und Sozialgeschichte einer griechischen Polis, Stuttgart 2017, s. 117-118. 
Hodowla koni i związane z nią uczestnictwo w hippikoi agones cieszyło się szczególną popularnością wśród przedstawicieli spartańskiej elity. Przeznaczanie poważnych środków na prowadzenie całego przedsięwzięcia służyło dwóm zasadniczym celom: manifestacji statusu majątkowego i zbijaniu kapitału politycznego. W Sparcie (podobnie jak wszędzie w Grecji) ewentualne zwycięstwo w zawodach sportowych, zwłaszcza na igrzyskach panhelleńskich, przynosiło sławę, którą można było wykorzystać do zdobycia politycznej przewagi w ojczystej polis. Wymownym świadectwem siły politycznej tych, którzy byli w stanie zaangażować się w hippotrophie (a właściwie harmatotrophię), była kampania propagandowa, jaką rozwinął przeciw nim król Agesilaos II. Promował on wprowadzoną za czasów wojny peloponeskiej hodowlę koni wojskowych zamiast hodowli koni wyścigowych. Efekty były odwrotne do zamierzonych: chcąc odwieść bogaczy od marnotrawienia funduszy i energii na aktywność nieprzynoszącą państwu korzyści wojskowych, doprowadził do włączenia się w rywalizację hippiczną zamożnych kobiet, które jako dziedziczki ziemi dysponowały niekiedy znacznym majątkiem. Wprowadzenie Kyniski na igrzyska olimpijskie (być może z jej własnej inicjatywy) nie tylko zatem podniosło popularność wyścigów konnych, ale także miało poważne konsekwencje dla refleksji nad spartańskim ustrojem społecznym i politycznym: poprzez naruszenie granic między tradycyjnymi rolami kobiet i mężczyzn przyczyniło się do uformowania poglądu o nadmiernej swobodzie i nieuporządkowaniu (anesis) spartańskich kobiet, a w efekcie postrzegania całej Sparty jako wspólnoty, w której kobiety miały niebagatelny wpływ na rządy. 